\title{
A review of nano and micro-encapsulated phytochemical compounds for disease management in agriculture
}

Una revision de nano y microencapsulados de compuestos fitoquímicos para manejo de enfermades en la agricultura

\section{Marco Antonio Tucuch-Pérez ${ }^{1}$ (D), Roberto Arredondo-Valdés ${ }^{2}$ (D), Elan Iñaky Laredo-Alcalá ${ }^{3}$ (D), Carmen Natividad Alvarado-Canche ${ }^{4}$ (DD , Francisco Daniel Hernández-Castillo ${ }^{1^{*}}$ (D)}

${ }^{1}$ Departamento de Parasitología, Universidad Autónoma Agraria Antonio Narro, Calzada Antonio Narro 1923, Col. Buenavista, 25315, Saltillo, Coahuila, México.

${ }^{2}$ Nanobiociencia, Facultad de Ciencias Químicas, Universidad Autónoma de Coahuila (UAdeC), Ing. J. Cárdenas Valdez S/N, Col. República, 25280, Saltillo, Coahuila, México.

${ }^{3}$ Centro de Investigación para la Conservación de la Biodiversidad y Ecología de Coahuila, Universidad Autónoma de Coahuila (UAdeC). ${ }^{4}$ Centro de Investigación en Química Aplicada, Boulevard Enrique Reyna H.140, Col. San José de los Cerritos, 25294, Saltillo, Coahuila, México.

${ }^{*}$ Corresponding author email: fdanielhc@hotmail.com

Reception date

April 9th, 2020

Acceptance date:

September 9th, 2020

Online publication date: May 14th, 2021

This is an open access

article distributed

according the Creative

Commons license terms.

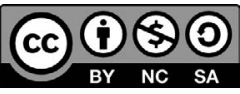

Reconocimiento-

NoComercia-

CompartirIgual 4.0

Internacional

\section{ABSTRACT}

Plant extracts (PEs) and essential oils (EOs) contain phytochemical compounds (PCs). Nevertheless, PCs can be degraded when applied on field. The use of nano-encapsulates (NEs) and micro-encapsulates (MEs) arise as an alternative to the application of botanical products. However, NEs and MEs with PCs in plant disease control have not been explored enough. This review discusses the use of PCs for plant disease control and the benefits obtained from formulations with NEs and MEs; furthermore, it discusses methods to produce NEs and MEs.

\section{KEYWORDS}

Plant extracts, essential oils, nanotechnology pesticides, biotechnology

\section{RESUMEN}

Los extractos de plantas (EP) y aceites esenciales (AE) contienen compuestos fitoquímicos (CFs). Sin embargo, estos CFs pueden degradarse cuando se aplican en campo. El uso de nano encapsulados (NEs) y micro encapsulados (MEs) surge como alternativa a la aplicación de productos botánicos. Sin embargo, los NEs y MEs con CFs en el control de enfermedades de plantas no se han explorado lo suficiente. Esta revisión discute el uso de CFs para control de enfermedades de plantas y beneficios otorgados por formulaciones con NEs y Mes, además de métodos para producir NEs y MEs.

\section{PALABRAS CLAVE}

Extractos de plantas, aceites esenciales, nanotecnología, pesticidas, biotecnología. 


\section{INTRODUCTION}

Agriculture is a pillar of humanity that provides basic products such as food, fuel, energy, wood, and others. Massive production should feed seven billion people and produce inputs for the economic and industrial process. Nevertheless, agricultural production is affected by diseases on-field and postharvest, affecting the yield and quality of the products obtained (Oliveira et al. 2014). Phytosanitary problems cause losses of up to 9.5 billions dollars worldwide, being one of the causes that could affect the food security of many countries (Conforti et al. 2018). Consequently, in agricultural production, disease control methods are adopted, being the chemical method the most widely used. However, the excessive and indiscriminate use of chemical products has brought on resistance development of the causal agents toward the active ingredients (García-Rojas et al. 2017; Carmona and Sautua 2017), and it has also affected the environment and human health (Ramírez-Legarreta and Jacobo-Cuéllar 2002).

The potential use of phytochemical compounds (PCs) with antimicrobial properties has been demonstrated at the laboratory, greenhouse, and field-level. These properties are given by chemical compounds like polyphenols and terpenoids, which form the defense mechanisms of the plants. Also the requirement to reduce the agrochemical use and change into organic and sustainable agriculture has made the use of PCs necessary for agricultural producers (Castillo et al. 2010; Erdoğan and Yildirim 2016; Jasso de Rodríguez et al. 2011). Nevertheless, although PCs are in several organic products used for disease control, there are some factors that reduce its effectiveness. Some of these factors are the oxidative degradation and active volatilization by humidity, temperature, and UV light, leaching of compounds by rains, and damage in plant organs caused by the solvents used (Armendáriz-Barragán et al. 2016; Bakry et al. 2016; Shishir et al. 2018).

Due to the problems mentioned above, the nanotechnology with nano encapsulates (NEs) of 1-100 $\mathrm{nm}$ and micro encapsulates (MEs) of 0.1-100 $\mu \mathrm{m}$ arise as an alternative for organic compound application. Both encapsulates can be from natural polymers such as chitosan, alginate, gelatin, and albumin, or synthetic polymers like methacrylate. In this sense, the development of disease control products with PCs through the nano and microencapsulation technology is a viable option to maintain their biological and functional characteristics (Armendáriz-Barragán et al. 2016; Bakry et al. 2016).

The size and physicochemical characteristics present in encapsulated natural products give them advantages such as compound encapsulation with a different chemical constitution in the same formulation, protection and conservation of the encapsulated compounds, natural elimination of the organic solvents during the particles development, gradual release of the encapsulated compounds, use of a smaller amount of product, storage at room temperature for prolonged periods, increased bioavailability of the assets, and masking of undesirable odors (Armendáriz-Barragán et al. 2016; Bakry et al. 2016; Bhattacharyya et al. 2016; Hernández-Suárez et al. 2010; Shishir et al. 2018). Briefly, the encapsulation consists of a core, which is the active compound that is to be encapsulated, and the wall or membrane which protects and coats the core (Bakry et al. 2016).

In agriculture, many scientists study the use of natural products encapsulated with natural polymers with slow degradation and without environmental impact, such as the chitosan and alginate that have biological activity in plants, conferring them resistance towards disease, even interacting directly with the pathogens due to their antifungal activity (Chandrasekar et al. 2014; Katiyar et al. 2015; Spadari et al. 2017; Verlee et al. 2017). At present, there are several methods for encapsulating actives, some of which are spray drying, extrusion, fluidized-bed-coating, emulsification, ionic gelation, coacervation, in situ polymerization, and the coaxial electrospray method (Bakry et al. 2016; Sagiri et al. 2016; Sandoval-Peraza et al. 2017).

Many types of research had addressed the use of encapsulated natural products for disease management. In this sense, Sattary et al. (2020) reported NEs of EOs from lemongrass and clove presented a better antifungal effect against Gaeumannomyces graminis (Sacc.) Arx \& D.L. Olivier than essential oils without encapsulating. This review aims to give an overview of PCs for disease control and nanotechnology to apply PCs focusing on NEs and MEs, their benefits, production techniques, and the application of this kind of product for crop protection. 


\section{PCs in agriculture}

A way to use PCs is the use of plant extracts (PEs) and essential oils (EOs), which are the most common plant products used for plant disease management. They are both concentrated and contain several compounds, but they differ in some characteristics: EOs are oily liquids obtained from plants through fermentation, effleurage and steam distillation (Burt 2004), whereas PEs are obtained from dried plant products by filtration and evaporation using various solvents (Wang et al. 2004). These extracts and oils have many properties conferred by the PCs, i.e., antifungal, antibacterial, antiviral, insecticidal, antioxidant, and resistance inducer (Chandrashekhara et al. 2010; Jasso de Rodríguez et al. 2011).

\section{Composition and action mode of PCs}

During the metabolism of plants biochemical reactions are generated. These derive in products called secondary metabolites, and plants have an unlimited ability to synthesize these metabolites (some of the leading PCs are in Figure 1). In plants, some of the most important secondary metabolites are terpenes, terpenoids, and aromatics due to their effects on microorganisms, mostly phenols or their oxygen-substituted derivatives. Some compounds found in these classes are phenols, phenolic acids, quinones, flavones, flavonoids, flavonols, tannins, coumarins, and alkaloids. These phytochemicals present several action modes on microorganisms (Altemimi et al. 2017; Calo et al. 2015; Hernández et al. 2015; Wink 2011).

Each compound has different action modes on microorganisms; the action mode depends on the metabolite structure. Phenolic compounds comprise a single substituted phenolic ring (Galal 2006). There is evidence that suggests that the number of hydroxyl groups on the phenolic ring are related to the degree of toxicity to microorganisms - with a higher number of hydroxyl groups the toxicity increase. Phenolic compounds alter permeability and interact with
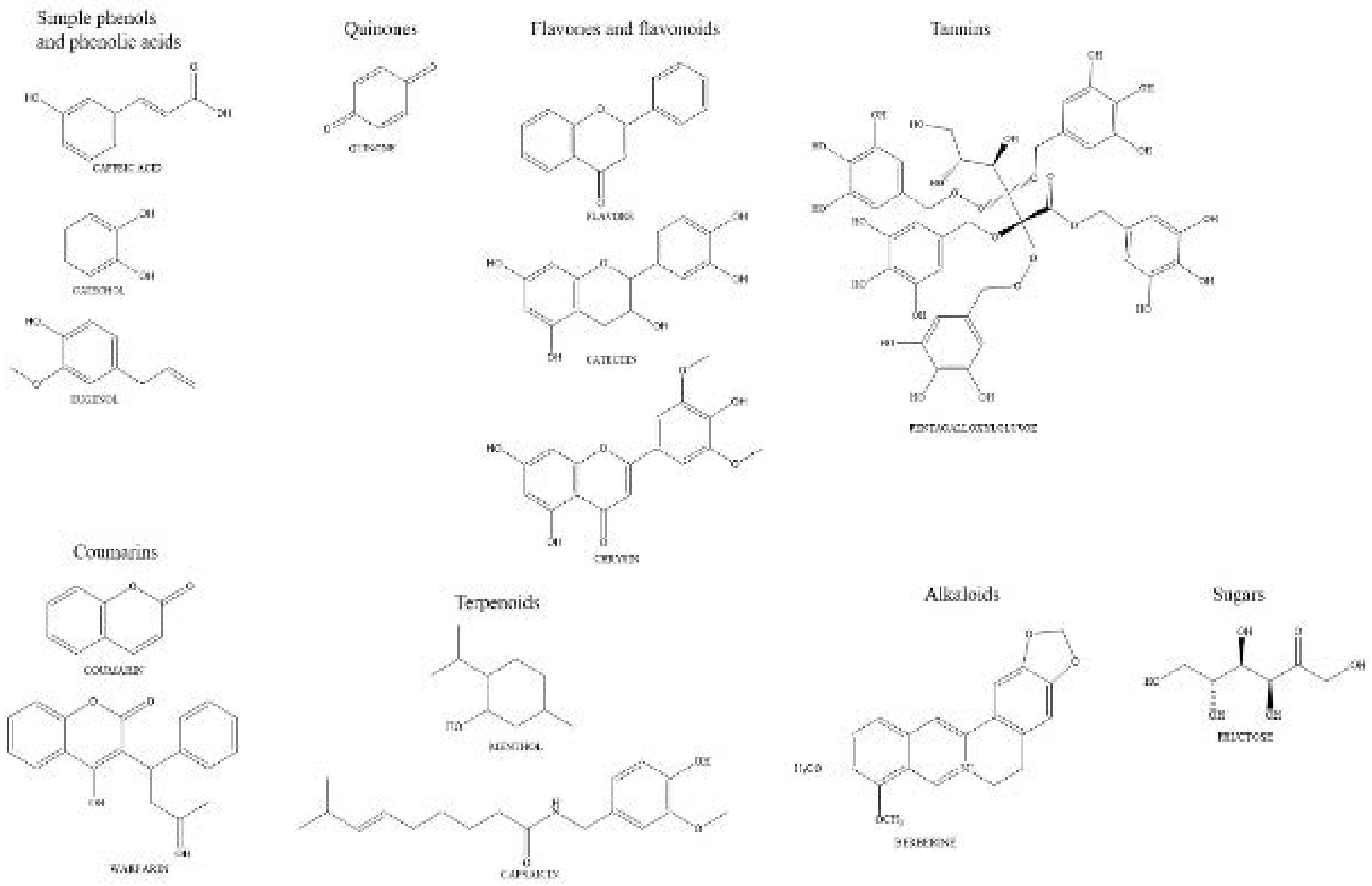

Figura 1 Chemical structures of leading groups of natural compounds. 
membrane proteins (Cabral et al. 2013; Hintz et al. 2015). Flavones, flavonoids, and flavonols present a carbonyl and a 3-hydroxyl group. They can inactivate proteins and enzymes and form a complex with cellular walls (Hintz et al. 2015; Pang et al. 2014). Quinones are formed by aromatic rings with two carbonyls, providing a stable source of free radicals; they are potent antimicrobial compounds to bind to and inactivate proteins. They may also make substrates unavailable to microorganisms (Cowan 1999; Hintz et al. 2015). Tannins have many phenolic rings in their structure, and they are classified into two groups: hydrolyzable formed by polymerization of quinones and condensed formed by condensation of flavan derivatives. The antimicrobial action mode is similar to quinones (Altemimi et al. 2017; Hintz et al. 2015). Coumarins are phenolic structures of fused benzene and alpha-pyrone ring. Their action mode is linked with DNA interaction (Cowan 1999; Venugopala et al. 2013). At last, the capability of phytochemicals for inducing systemic resistance, or at least defense responses, has also been reported, as an action mode. This action mode has not been explained entirely, but some research indicates that the mix of diverse compounds as inorganic compounds, secondary metabolites and signaling molecules influence plant metabolism synergistically and either directly activate or prime the treated plant to prompt a response to the pathogen (Burketova et al. 2015).

\section{Plants as a source of PCs: application in agriculture for disease control}

Agriculture is a crucial activity for humanity because it provides food and other necessary products. Nevertheless, phytosanitary problems caused by the use of chemical pesticides bring about ecological resistance, and health problems. The use of PCs arises as an ecological solution; some plants contain components that are toxic to pathogens. When extracted from the plant and applied on infested crops, these components are called botanical pesticides or botanicals.

Many reports approve the efficacy of several kinds of plants controlling phytopathogenic organisms. These plants contain different PCs depending on the plant species and even rely on the plant organ as the stem, bark, roots, and leaves (Table 1). Lippia graveolens Kunth extracts with ethanol as a solvent have tannins and flavonoids that inhibit the growth of phytopathogens by $100 \%$, such as Rhizopus stolonifer Vouillemin, Colletotricum gloesporoides Penz, and Penicillium digitatum (Pers.) Sacc., (Jasso de Rodríguez et al. 2011). Other plants with good antimicrobial effects are Larrea tridentate (Moc. \& Seseé ex Dc.), Flourensia cernua DC., Opuntia ficus-indica (L.) Mill., Agave lechuguilla Torr., and Yucca filifera Chabaud. These species are abundant in PCs, as mentioned by Castillo-Reyes et al. (2015), who extracted polyphenols from these species and used them to control Rhizoctonia solani Kühn in vitro, an important phytopathogen for several crops. Eysenhardtia polystachya (Ortega) Sarg. is a desertic plant used in traditional craft making. This species presents isoflavones in its sapwood and heartwood. A study revealed that the dichloromethane extracts from these parts inhibited mycelial growth of Sclerotium cepivorum Berk. by $80 \%$ and $73 \%$, respectively (Rodríguez-Guadarrama et al. 2018). Azadirachta indica A. Juss., commonly known as neem, has phytochemicals such as azadirachtin, which is a triterpenoid able to control Puccinia triticina Erikss. on wheat by $85 \%$ to $90 \%$ under field conditions. The action mode of this extract and its PCs is not clear; nevertheless, the induced resistance phenomenon is considered as the main mechanism for P. triticina control, due to the increase of plant defenses and the production of defense substances such as the enzyme peroxidase or the accumulation of phenolic compounds (Shabana et al. 2017).

Essential oils are also an excellent organic method to control diseases in agriculture, and they have PCs which can inhibit and control the growth of phytopathogens. Sharma et al. (2017) mentioned the antifungal effect of Syzygium aromaticum (L.) Merr. \& L.M.Perry essential oil on Fusarium oxysporum Schltdl. This product inhibited the fungal growth by $100 \%$ in vitro. The antimicrobial activity was attributed to the eugenol and caryophyllene compounds. Melissa officinalis L. is a plant whose essential oil inhibited the growth of Botrytis cinerea Whetzel, Penicillium expansum Link, and R. stolonifera. In this case, there was also a high inhibition due to the compounds P-mentha- 1,2,3-triol, P-menth-3-en-8-ol, piperitenone oxide and Zpiperitone oxide (El Ouadi et al. 2017). However, the activity against phytopathogens cannot 
Table 1. Source of phytochemicals and their activity against phytopathogen fungus.

\begin{tabular}{|c|c|c|c|c|c|}
\hline $\begin{array}{l}\text { Source of } \\
\text { phytochemicals }\end{array}$ & Compounds & Phytopathogen & $\begin{array}{l}\text { Type of } \\
\text { product }\end{array}$ & Activity & Reference \\
\hline Lippia graveolens & $\begin{array}{l}\text { Tannins and } \\
\text { flavonoid }\end{array}$ & $\begin{array}{l}\text { R. stolonifer, } \\
\text { Colletotricum } \\
\text { gloesporoides, and P. } \\
\text { digitatum }\end{array}$ & $\begin{array}{l}\text { Plant } \\
\text { extract }\end{array}$ & Antifungal & $\begin{array}{l}\text { Jasso de } \\
\text { Rodríguez et al. } \\
\text { (2011) }\end{array}$ \\
\hline $\begin{array}{l}\text { Larrea tridentata, } \\
\text { Flourensia cernua, } \\
\text { Opuntia ficus-indica, } \\
\text { Agave lechuguilla } \\
\text { and Yucca filifer }\end{array}$ & Polyphenols & Rhizoctonia solani & $\begin{array}{l}\text { Plant } \\
\text { extract }\end{array}$ & Antifungal & $\begin{array}{l}\text { Castillo et al. } \\
\text { (2015) }\end{array}$ \\
\hline $\begin{array}{l}\text { Eysenhardtia } \\
\text { polystachya }\end{array}$ & Isoflavones & Sclerotium cepivorum & $\begin{array}{l}\text { Plant } \\
\text { extract }\end{array}$ & Antifungal & $\begin{array}{l}\text { Rodriguez- } \\
\text { Guadarrama et } \\
\text { al. (2018) }\end{array}$ \\
\hline Azadirachta indica & Azadirachtin & Puccinia triticina & $\begin{array}{l}\text { Plant } \\
\text { extract }\end{array}$ & Antifungal & $\begin{array}{l}\text { Shabana et al. } \\
\text { (2017) }\end{array}$ \\
\hline $\begin{array}{l}\text { Syzygium } \\
\text { aromaticum }\end{array}$ & $\begin{array}{l}\text { Eugenol and } \\
\text { caryophyllene }\end{array}$ & Fusarium oxysporum & $\begin{array}{l}\text { Essential } \\
\text { oil }\end{array}$ & Antifungal & $\begin{array}{l}\text { Sharma et al. } \\
\text { (2017) }\end{array}$ \\
\hline Melissa officinalis & $\begin{array}{l}\text { P-mentha-1,2,3-triol, } \\
\text { P-menth-3-en-8-ol, } \\
\text { piperitenone oxide } \\
\text { and Zpiperitone } \\
\text { oxide }\end{array}$ & $\begin{array}{l}\text { Botrytis cinerea, } P \text {. } \\
\text { expansum, and } R \text {. } \\
\text { stolonifer }\end{array}$ & $\begin{array}{l}\text { Essential } \\
\text { oil }\end{array}$ & Antifungal & $\begin{array}{l}\text { El Ouadi et al. } \\
\text { (2017) }\end{array}$ \\
\hline $\begin{array}{l}\text { Gaultheria } \\
\text { procumbens }\end{array}$ & Methylsalicylate & C. higginsianum & $\begin{array}{l}\text { Essential } \\
\text { oil }\end{array}$ & $\begin{array}{l}\text { Resistance } \\
\text { inductor }\end{array}$ & $\begin{array}{l}\text { Vergnes et al. } \\
(2014)\end{array}$ \\
\hline sugar beet extract & $\begin{array}{l}\text { P-hydroxybenzoic } \\
\text { acid }\end{array}$ & $\begin{array}{l}\text { Phytophthora } \\
\text { infestans }\end{array}$ & $\begin{array}{l}\text { Plant } \\
\text { extract }\end{array}$ & $\begin{array}{l}\text { Resistance } \\
\text { inductor }\end{array}$ & $\begin{array}{l}\text { Moushib et al. } \\
\text { (2013) }\end{array}$ \\
\hline Viscum album & $\begin{array}{l}\text { Alkenes and } \\
\text { aromatics } \\
\text { compounds }\end{array}$ & $\begin{array}{l}\text { Sclerospora } \\
\text { graminicola }\end{array}$ & $\begin{array}{l}\text { Plant } \\
\text { extract }\end{array}$ & $\begin{array}{l}\text { Resistance } \\
\text { inductor }\end{array}$ & $\begin{array}{l}\text { Chandrashekhara } \\
\text { et al. (2010) }\end{array}$ \\
\hline
\end{tabular}

be triggered by the antifungal activity directly since there are some PCs capable of inducing resistance in plants against phytopathogens. Regarding this issue, Vergnes et al. (2014) reported the activation of resistance genes in Arabidopsis thaliana (L.) Heynh. by the essential oil of Gaultheria procumbens L. against Colletotrichum higginsianum Sacc. due to the methylsalicylate compound, which can be metabolized in plant tissues to salicylic acid, a phytohormone inducing plant immunity against microbial pathogens. Likewise, Moushib et al. (2013) reported the activation of pathogenesis-related proteins in potato plants against Phytophthora infestans (Mont.) de Bary with the exogenous application of sugar beet extract due to phenolic compounds like the p-hydroxybenzoic acid, a derivative of benzoic acid. Another plant extract reported as a resistance inducer is Viscum album L. extract, which contains alkenes and aromatic compounds, which could induce resistance in Pennisetum glaucum (L.) R.Br. plants against Sclerospora graminicola (Sacc.) Schröter. (Chandrashekhara et al. 2010). 


\section{NANOTECHNOLOGY AND ITS APPLICATION IN AGRICULTURE}

Although PCs are an excellent solution to counter the resistance and ecological problems caused by chemical compounds against diseases in agriculture, and although their application in vitro and in vivo have shown promising results, when carrying the formulated product to the field, the results are not as expected many times. Studies have shown that their use is still limited because biological products like PEs and EOs can readily degrade when exposed to environmental factors such as light, temperature, humidity, and UV light. Leaching of compounds by rains and all these factors result in loss of activity, being just $0.1 \%$ of the product applied which reaches the target (Armendáriz-Barragán et al. 2016, Bakry et al. 2016; Grillo et al. 2014; Shishir et al. 2018; Pereira et al. 2017). Hence, there is a need to develop formulations to improve the stability and effectiveness of these natural compounds in different applications (De Oliveira et al. 2018). An alternative is the use of nanotechnology, defined as the manipulation of matter on a scale from 1-100 nm and which involves the development of materials or devices with that size (Satalkar et al. 2016). Nanotechnology in agriculture could be applied in several modes (Table 2). Nanocides are the most studied nanotechnology application in agriculture. They include natural fungicides and insecticides like plant extracts and essential oils, but they are also applied to technologies such as buckyball fertilizers, nanoparticles, food packaging, use of agricultural waste, nanosensors, precision farming, livestock and fisheries (Mukhopadhyay 2014).

\section{NEs and MEs of PCs for crop protection}

Due to the aforementioned constraints for the application of PCs against diseases on the field, the use of polymers for encapsulation of active ingredients is a novel technique of crop protection, which involves dissolving, entrapping, encapsulating, or attaching active ingredients to NEs or MEs (Roy et al. 2014). Generally, encapsulates consist of core material, referred to as the internal phase or fill, and a wall referred to as the coating, shell, or membrane (Bakry et al. 2016). Wall material is essential to determine the stability of encapsulates, the process efficiency, and the degree of protection. For the production of encapsulates, the material of the wall may be formed by synthetic products, but in crop protection, there is an interest in nontoxic, biodegradable polymers which degrade by a chemical process and microbiological breakdown, thus not affecting the environment. Some materials used as natural polymers for the wall may

\section{Table 2. Examples of nanotechnology applications in agriculture.}

\begin{tabular}{|c|c|c|}
\hline Nanopesticides & Pesticides encapsulated in nanoparticles for controlled release & Mukhopadhyay (2014) \\
\hline Nano fertilizers & Nanomaterials as agents to stimulate plant growth & Fraceto et al. (2016) \\
\hline Nanobiosensors & Detection of pathogens and plagues in crops & Prasad et al. (2017) \\
\hline $\begin{array}{l}\text { Food packing and } \\
\text { labeling }\end{array}$ & $\begin{array}{l}\text { The food package color changes when a change in food } \\
\text { structure occurs as oxidation or decomposition }\end{array}$ & Prasad et al. (2017) \\
\hline Precision farming & $\begin{array}{l}\text { Nanosensors linked to a global positioning system tracking } \\
\text { unit for real-time monitoring of soil conditions and crop } \\
\text { growth }\end{array}$ & Mukhopadhyay (2014 \\
\hline $\begin{array}{l}\text { Wastwater } \\
\text { treatment }\end{array}$ & $\begin{array}{l}\text { Wastewater treatment with nanoparticles that realize } \\
\text { photocatalysis }\end{array}$ & Ditta (2012) \\
\hline Soil remediation & $\begin{array}{l}\text { Nanomaterials and devices used to remove contaminants from } \\
\text { soil }\end{array}$ & Rabbani et al. (2016) \\
\hline Nano-coating & $\begin{array}{l}\text { Coatings/films for crop harvesting and storage of agricultural } \\
\text { products as seeds, plants, and fruits }\end{array}$ & Iavicoli et al. (2017) \\
\hline
\end{tabular}


be polysaccharides like alginates, carrageenans, agar/ agarose, gellan gum, guar gum, acacia gum, starch, starch-based materials, cellulose, pectin, chitosan, including derivates thereof, polypeptides such as poly-L-lysin, or proteins like gelatin or whey lipids like waxes or other biopolymers such as lignin (Armendáriz-Barragán et al. 2016; Bakry et al. 2016; Roy et al. 2014; Vemmer and Patel 2013).

\section{Benefits of NEs and MEs of PCs in agriculture}

Natural plant products such as PEs and EOs have gained interest in disease control use because of their low environmental impact. Still, many research types indicate the improvement of these natural products when they apply on the field in NEs and MEs. There are several advantages of NEs and MEs when they are applied to the field. These benefits are essential because they enhance the efficiency of the effect of compounds on the microorganisms, allowing complete protection of the plant, which further brings more benefits to the plants. NEs and MEs avoid the degradation and protect the active compounds when they are on storage or when they are applied in the field through the membrane polymer (Armendáriz-Barragán et al. 2016). Due to the properties of the polymers, the release of active ingredients on the plant can be regulative, allowing a constant level of the active agent over an extended period, smaller doses, reduction of evaporative losses, reduction of phytotoxicity, decrease in environmental pollution, and ease in handling (Roy et al. 2014; Vemmer and Patel 2013). Sorption and leaching also pose problems in the field when natural products are applied. Nevertheless, the physical chemistry characteristic of NEs and MEs reduce these problems (Pereira et al. 2017). An essential issue in agriculture is the non-target organism contamination by applied products in crops, in this sense, encapsulates have proven to have greater efficacy against target organisms and lower toxicity to non-target organisms (Kah and Hofmann 2014). Also when formulates of NEs and MEs are developed, they may encapsulate a mix of the compounds and remove unpleasant odors (Armendáriz-Barragán et al. 2016).

Furthermore, the natural polymers used in NEs and MEs have other benefits on the plants, changing the metabolism of plants or affecting the phytopathogens. Chitosan is a linear copolymer that is widely used for the encapsulation of bioactive compounds due to its biocompatibility, low toxicity, low cost, and biodegradability (Pereira et al. 2017), which has shown to be capable of inducing resistance in plants against microorganisms through enhanced activation of enzymes as catalase and phenylalanine ammonia-lyase (Nandeeshkumar et al. 2008), apart from presenting direct antifungal activity against microorganisms (Ing et al. 2012). Sodium alginate is also a copolymer used to produce NEs and MEs that show the ability to promote plant growth when treated and applied directly on plants (El-Mohdy 2017). Another natural polymer is pectin. There is evidence of its capacity to enhance the colonization and secretion of secondary metabolites by beneficial bacteria such as Bacillus spp. (Wu et al. 2015), and carrageenans that can also induce resistance in plants against diseases (Bi et al. 2011).

\section{Encapsulation techniques of PCs}

Numerous techniques have been used for the microencapsulation of PCs. We will mention the most common processes to encapsulate using natural polymers to encapsulate phytochemicals for their application in agriculture.

\section{Nanoprecipitation}

Nanoprecipitation is a simple, reproducible, and economical technique suitable for encapsulating hydrophilic and hydrophobic phytochemical compounds. In this technique, two miscible phases need an organic and an aqueous phase. The organic phase contains the polymer solution in an organic solvent and the phytochemical compound to encapsulate; the aqueous phase contains a non-solvent for polymers. In this technique, a rapid desolvation of the polymer occurs when the organic phase is added to the aqueous phase, inducing the direct encapsulation of the compounds (El Asbahani et al. 2015; Salatin et al. 2017). Suwannateep et al. (2011) applied the nanoprecipitation method to obtain nanocapsules of ethylcellulose polymeric charged with curcumin. These NPs showed cytotoxic activity. 


\section{Spray drying}

It is one of the most widely used techniques to produce microencapsulates because it is economical, flexible, and continuous. It has particles whose size is 10-40 $\mu \mathrm{m}$ approximately. The spray drying process converts a liquid into a stable powder. A liquid mix containing a solution of polymers and the actives are loaded into a spray-dryer and atomized into a drying chamber where there is a continuous hot air flow. Then the solvent, mainly water, is evaporated, and powder with microencapsulates is formed (Jia et al. 2016; Nedovic et al. 2011). Nunes et al. (2015) produced MEs of Ilex paraguariensis A.St.-Hil. extract by spray drying, and observed excellent retention of phenolic compounds after 45 days.

\section{Ionic gelation}

The principle of this method is the electrostatic interaction between a polymer and a polyelectrolyte oppositely charged. To form the encapsulates, a charged polymer solution is mixed with the encapsulating material (PCs) and then is added dropwise under constant starring to a different polyelectrolyte causing the cross-linking to form the particles (Armendáriz-Barragán et al. 2016; Sagiri et al. 2016). Ionic gelation method allowed obtaining encapsulates using alginate and chitosan as a shell to encapsulate anthocyanins from Euterpe edulis Mart., increasing stability and protecting the anthocyanins from environmental conditions that interfere with their stability and color (Carvalho et al. 2019).

\section{Coacervation}

It is a standard method to form encapsulates. This technique involves the electrostatic attraction between two polymers and the coacervates formation. It is classified as simple coacervation whenever only a polymer is used, or complex coacervation when two polymers are used. The process consists of adding one or two polyelectrolytes in a solution called the . The coacervate phase with coacervates is deposited around the compound to encapsulate; the formed shell can be cross-linked with a chemical or enzymatic crosslinker to enhance its robustness. This process is affected by $\mathrm{pH}$, temperature, ionic strength, molecular weight, and concentration (Bakry et al. 2016; Jia et al. 2016; Vemmer and Patel 2013). MEs of essential oil from Peumus boldus Molina were produced by complex coacervation, enhancing the efficiency of the antifungal activity, allowing the protection against Penicillium sp. and Aspergillus sp. 114 days in peanut seeds (Girardi et al. 2016).

\section{Extrusion}

This method allows encapsulate compounds of interest with a biopolymer solution. The matrix materials pass through a nozzle into a gelling environment on a small scale with a syringe and are applied to an industrial scale. This technique may encapsulate a large variety of hydrophilic or hydrophobic compounds. The nozzle size regulates the particles' size in the sprayer; the encapsulates can be incubated in a crosslinker solution to enhance their characteristics (Jia et al. 2016; Sagiri et al. 2016; Shishir et al. 2018). Arriola et al. (2016) produced encapsulates from Stevia rebaudiana Bertoni through the extrusion method and obtained calcium alginate encapsulates, which showed stability in total phenolic content and antioxidant potential after 30 days of storage.

\section{Application of NEs and MEs of PCs for phytopathogens control}

Several kinds of research and works on plant protection focus on PCs application as PEs and EOs, due to the necessity of organic agriculture. In this context, an alternative for the application of these organic products has been sought for. NEs and MEs are a good option because of the advantages and benefits shown above. In this sense, Mohammadi et al. (2015) reported a formulated product which contained NEs of chitosan loaded with Zataria multiflora Boiss. essential oil. This product showed an excellent antifungal effect against $B$. cinerea, both in vitro and in vivo assay. Other examples are the production of NEs with cinnamon leaf, lemon, and bergamot essential oil, which are loaded with compounds like eugenol and D-limonene. These NEs were effective for the control of A. niger in vitro (Ribes et al. 2017), while the production of NEs of Cuminum cyminum L. essential 
oil in chitosan-caffeic acid nano-gel for the control of Aspergillus flavus Link., which affects extensive crops (Zhaveh et al. 2015). The use of encapsulates is also a good option for postharvest management of crops, as mentioned by Mohammadi et al. (2016), who achieved to improve antioxidant activity and extend the shelf-life of cucumber using NEs loaded with Z. multiflora essential oil.

The use of MEs is another alternative to the application of PCs for control of microorganisms. Rossetti et al. (2017) reported the microencapsulation of gallic acid and ellagic acid to control of Pseudomonas syringae Van Hall and P. viridiflava Dowson in kiwi fruits. They obtained a reasonable control of the disease in vitro, under greenhouse conditions and with fruits in postharvest. Other work with MEs is the one reported by Matouskova et al. (2016), in which they presented MEs of several PEs with antimicrobial activity against two Gram-positive (Bacillus subtilis Cohn and Micrococcus luteus Schröter. Cohn.) and a Gram-negative (Escherichia coli Escherich) bacteria. Finally, there is the work of Wang et al. (2018), who used chitosan produced MEs loaded with clove essential oil for the control of $P$. digitatum in Novel orange. Although encapsulates of PCs controlled the phytopathogenic organism directly, they may also induce resistance against diseases. An example is a formulation with MEs of coffee leaf extracts or gallic acid as plant resistance inducers (Corrêa et al. 2016), and the use of allicin encapsulated obtained from garlic extract also to induce resistance against phytopathogens in some crops (Slusarenko et al. 2008). This kind of formulated product is a good option in agriculture; thus, universities and companies have been investing resources in developing products or techniques to produce encapsulates, which may be profitable. Some examples are the developed patent by the Universidad de Santiago de Chile, which made a microencapsulated natural fungicidal formulation comprising extracts of grape marc or pomace, for controlling infestation by $B$. cinerea in plants (Cotoras-Tadic et al. 2016); and also the patent developed by the Ben-Gurion University of the Negev that provides a process to produce essential oils microcapsules suitable for use as disinfectants, pesticides, insect repellants, antiviral and antifungal agents (Markus and Linder 2015).

\section{CONCLUSION}

Plants synthesize a range of $\mathrm{PCs}$, which are an excellent option for disease management; however, the potential of these compounds has been underestimated because the efficacy of PCs may be affected by environmental factors, mainly when products that contain PCs like PEs or EOs are applied on the field. To reduce the loss of effectiveness of compounds, low-cost formulations can be used in which the nanotechnology arise as an alternative, specifically, the NEs and MEs, allowing the development of novel plant-based products. However, commercial product development depends on financial viability and operational processes. Finally, although the use of NEs and MEs of PCs is an alternative for crop protection and disease control, it is still necessary to research how to improve formulations and offer more ecological options for plant pathologists.

\section{ACKNOWLEDGMENTS}

This work was supported by the Consejo Nacional de Ciencia y Tecnología, with the scholarship number 708037, and with the support of the Universidad Autónoma Agraria Antonio Narro (project number 2003). 


\section{LITERATURE CITED}

Altemimi A, Lakhssassi N, Baharlouei A, Watson DG, Lightfoot DA. 2017. Phytochemicals: Extraction, isolation, and identification of bioactive compounds from plant extracts. Plants 6: 42. https://doi.org/10.3390/ plants6040042

Armendáriz-Barragán B, Zafar N, Waisudin B, GalindoRodríguez SA, Kabbaj D, Fessi H, Elaissari A. 2016. Plant extracts: From encapsulation to application. Expert Opinion on Drug Delivery 13: 1165-1175. https:// doi.org/10.1080/17425247.2016.1182487

Arriola NDA, de Medeiros PM, Prudencio ES, Muller CMO, Amboni RDdMC. 2016. Encapsulation of aqueous leaf extract of Stevia rebaudiana Bertoni with sodium alginate and its impact on phenolic content. Food Bioscience 13: 32-40. http://doi.org/10.1016/j.fbio.2015.12.001

Bakry AM, Abbas S, Ali B, Majeed H, Abouelwafa MY, Mousa A, Liang L. 2016. Microencapsulation of oils: A comprehensive review of benefits, techniques, and applications. Comprehensive Reviews in Food Science and Food Safety 15: 143-182. https://doi. org/10.1111/1541-4337.12179

Bhattacharyya A, Duraisamy P, Govindarajan M, Buhroo AA, Prasad R. 2016. Nano-biofungicides: Emerging trend in insect pest control. In: Prasad R, editor. Advances and Applications through Fungal Nanobiotechnology. Cham, Springer. P. 307-319.

Bi F, IqbalS, Arman M, Ali A, Hassan MU. 2011. Carrageenan as an elicitor of induced secondary metabolites and its effects on various growth characters of chickpea and maize plants. Journal of Saudi Chemical Society 15: 269273. https://doi.org/10.1016/j.jscs.2010.10.003

Burketova L, Trda L, Ott PG, Valentova O. 2015. Bio-based resistance inducers for sustainable plant protection against pathogens. Biotechnology Advances 33: 9941004. https://doi.org/10.1016/j.biotechadv.2015.01.004

Burt S. 2004. Essential oils: Their antibacterial properties and potential applications in foods-a review. International Journal of Food Microbiology 94: 223-253. https://doi.org/10.1016/j.ijfoodmicro.2004.03.022

Cabral LC, Pinto VF, Patriarca A. 2013. Application of plant derived compounds to control fungal spoilage and mycotoxin production in foods. International Journal of Food Microbiology 166: 1-14. https://doi.org/10.1016/j. ijfoodmicro.2013.05.026

Calo JR, Crandall PG, O'Bryan CA, Ricke SC. 2015.
Essential oils as antimicrobials in food systems-A review. Food Control 54: 111-119. https://doi.org/10.1016/j. foodcont.2014.12.040

Carmona M, Sautua F. 2017. La problemática de la resistencia de hongos a fungicidas. Causas y efectos en cultivos extensivos. Agronomía \& Ambiente 37: 1-19.

Carvalho AGS, Machado MTC, Barros HDDFQ, Cazarin CBB, Junior MRM, Hubinger MD. 2019. Anthocyanins from jussara (Euterpe edulis Martius) extract carried by calcium alginate beads pre-prepared using ionic gelation. Powder Technology 345: 283-291. https://doi. org/10.1016/j.powtec.2019.01.016

Castillo F, Hernández D, Gallegos G, Mendez M, Rodríguez R, Reyes A, Aguilar CN. 2010. In vitro antifungal activity of plant extracts obtained with alternative organic solvents against Rhizoctonia solani Kühn. Industrial Crops and Products 32: 324-328. https://doi.org/10.1016/j. indcrop.2010.05.013

Castillo-Reyes F, Hernández-Castillo FD, Gallegos-Morales G, Flores-Olivas A, Rodríguez-Herrera R, Aguilar CN. 2015. Efectividad in vitro de Bacillus y polifenoles de plantas nativas de México sobre Rhizoctonia-Solani. Revista Mexicana de Ciencias Agrícolas 6: 549-562.

Chandrasekar S, Vijayakumar S, Rajendran R. 2014. Application of chitosan and herbal nanocomposites to develop antibacterial medical textile. Biomedicine \& Aging Pathology 4: 59-64. https://doi.org/10.1016/j. biomag.2013.10.007

Chandrashekhara S, Niranjan S, Manjunath G, Deepak S, Shekar H. 2010. Seed treatment with aqueous extract of Viscum album induces resistance to pearl millet downy mildew pathogen. Journal of Plants Interactions 5: 283291. https://doi.org/10.1080/17429140903556539

Conforti P, Ahmed S, Markova G. [internet]. 2018. Impact of disasters and crises on agriculture and food security, 2017. [cited 2019 September 23]. Available in: http://agris.fao. org/agris-search/search.do?recordID=XF2018001268.

Corrêa JLG, Mendonça KS, Rodrigues LR, Resende MLV, Alves GE. 2016. Spray drying of coffee leaf extract. Coffee Science 11: 359-367.

Cotoras-Tadic M, Mendoza-Espinola LS, Bustos-Cerda RO, Grancelli-Oliveira A, Godoy-Pedraza D. [internet]. 2016. WO 2016/106467 Al. World Intellectual Property Organization. [cited 2019 November 10]. Available in: https://patentscope.wipo.int/search/es/detail. jsf?docId=WO2016106467\&redirectedID=true.

Cowan MM. 1999. Plant products as antimicrobial agents. 
Clinical Microbiology Reviews 12: 564-582. https://doi. org/10.1128/CMR.12.4.564

De Oliveira JL, Campos EVR, Pereira AES, Nunes LES, da Silva CCL, Pasquoto T, Lima R, Smaniotto G, Polanczyk RA, Fraceto LF. 2018. Geraniol encapsulated in chitosan/gum arabic nanoparticles: A promising system for pest management in sustainable agriculture. Journal of Agricultural and Food Chemistry 66: 5325-5334. https://doi.org/10.1021/acs.jafc.8b00331

Ditta A. 2012. How helpful is nanotechnology in agriculture? Advances in Natural Sciences. Nanoscience and Nanotechnology 3: 033002.

El Asbahani A, Miladi K, Badri W, Sala M, Addi EHA, Casabianca H, El Moousadik A, Hartmann D, Jilale A, Renaud FNR, Elaissari A. 2015. Essential oils: From extraction to encapsulation. International Journal of Pharmaceutics 483: 220-243. https://doi.org/10.1016/j. ijpharm.2014.12.069

El Ouadi Y, Manssouri M, Bouyanzer A, Majidi L, Bendaif H, Elmsellem H, Shariati MA, Melhaoui A, Hammouti B. 2017. Essential oil composition and antifungal activity of Melissa officinalis originating from north-Est Morocco, against postharvest phytopathogenic fungi in apples. Microbial Pathogenesis 107: 321-326. https://doi. org/10.1016/j.micpath.2017.04.004

El-Mohdy HLA. 2017. Radiation-induced degradation of sodium alginate and its plant growth promotion effect. Arabian Journal of Chemistry 10: S431-S438. https://doi. org/10.1016/j.arabjc.2012.10.003

Erdoğan P, Yildirim A. 2016. Insecticidal activity of three different plant extracts on the green peach aphid [(Myzus persicae Sulzer) (Hemiptera: Aphididae)]. Journal of the Entomological Research Society 18: 27-35.

Fraceto LF, Grillo R, de Medeiros GA, Scognamiglio V, Rea G, Bartolucci C. 2016. Nanotechnology in agriculture: Which innovation potential does it have? Frontiers in Environmental Science 4: 20. https://doi.org/10.3389/ fenvs.2016.00020

Galal AM. 2006. Natural product-based phenolic and nonphenolic antimicrobial food preservatives and 1, 2, 3, 4-tetrahydroxybenzene as a highly effective representative: A review of patent literature 2000-2005. Recent Patents on Anti-infective Drug Discovery 1: 231-239. https://doi.org/10.2174/157489106777452610

García-Rojas JC, Robles-Bermúdez A, Cambero-Campos OJ, Carvajal-Cazola CR, Peña-Sandoval GR. 2017. Resistencia metabólica a insecticidas. Revista Bio
Ciencias 4: 1-16. https://doi.org/10.15741/revbio.04.06.01 Girardi NS, García D, Robledo SN, Passone MA, Nesci A, Etcheverry M. 2016. Microencapsulation of Peumus boldus oil by complex coacervation to provide peanut seeds protection against fungal pathogens. Industrial Crops and Products 92: 93-101. https://doi.org/10.1016/j. indcrop.2016.07.045

Grillo R, Pereira AES, Nishisaka CS, de Lima R, Oehlke K, Greiner R, Fraceto LF. 2014. Chitosan/tripolyphosphate nanoparticles loaded with paraquat herbicide: An environmentally safer alternative for weed control. Journal of Hazardous Materials 278: 163-171. https:// doi.org/10.1016/j.jhazmat.2014.05.079

Hernández T, García-Bores AM, Serrano R, Ávila G, Dávila P, Cervantes H, Peñalosa I, Flores-Ortiz CM, Lira R. 2015. Fitoquímica y actividades biológicas de plantas de importancia en la medicina tradicional del Valle de Tehuacán-Cuicatlán. TIP. Revista Especializada en Ciencias Químico-Biológicas 18: 116-121. https://doi. org/10.1016/j.recqb.2015.09.003

Hernández-Suárez M, Hernández-Castillo FD, LiraSaldivar RH, Gallegos-Morales G. 2010. Biocontrol de Rhizoctonia solani y Fusarium sp. con microencapsulados de Bacillus subtilis y su efecto en crecimiento y rendimiento de tomate (Lycopersicon esculentum Mill.). Revista Agraria Nueva Época 7: 17-25.

Hintz T, Matthews KK, Di R. 2015. The use of plant antimicrobial compounds for food preservation. BioMed Research International 2015: 246264. https://doi. org/10.1155/2015/246264

Iavicoli I, Leso V, Beezhold DH, Shvedova AA. 2017. Nanotechnology in agriculture: Opportunities, toxicological implications, and occupational risks. Toxicology and Applied Pharmacology 329: 96-111. https://doi. org/10.1016/j.taap.2017.05.025

Ing LY, Zin NM, Sarwar A, Katas H. 2012. Antifungal activity of chitosan nanoparticles and correlation with their physical properties. International Journal of Biomaterials 2012: 632698. http:// doi.org/10.1155/2012/632698

Jasso de Rodríguez DJ, Rodríguez R, Hernández FD, Aguilar CN, Sáenz A, Villareal JA, Moreno LE. 2011. In vitro antifungal activity of extracts of Mexican Chihuahuan Desert plants against postharvest fruit fungi. Industrial Crops and Products 34: 960-966. https:// doi.org/10.1016/j.indcrop.2011.03.001

Jia Z, Dumont M-J, Orsat V. 2016. Encapsulation of phenolic compounds present in plants using protein 
matrices. Food Bioscience 15: 87-104. https://doi. org/10.1016/j.fbio.2016.05.007

Kah M, Hofmann T. 2014. Nanopesticide research: Current trends and future priorities. Environment International 63: 224-235. https://doi.org/10.1016/j. envint.2013.11.015

Katiyar D, Hemantaranjan A, Singh B. 2015. Chitosan as a promising natural compound to enhance potential physiological responses in plant: A review. Indian Journal of Plant Physiology 20: 1-9. https://doi. org/10.1007/s40502-015-0139-6

Markus A, Linder C. [internet]. 2015. US 9,079,152 B2. Israel. World Intellectual Property Organization. [cited 2019 November 10]. Available in: http://patft.uspto. gov/netacgi/nph-Parser?Sect $1=$ PTO1\&Sect2=HITOFF $\& d=P A L L \& p=1 \& u=\% 2 F n e t a h t m l \% 2 F P T O \% 2 F s-$ rchnum.htm\&r=1\&f=G\&l=50\&s1=9,079,152.PN.\&OS= PN/9,079,152\&RS=PN/9,079,152.

Matouskova P, Marova I, Bokrova J, Benesova P. 2016. Effect of encapsulation on antimicrobial activity of herbal extracts with lysozyme. Food Technology and Biotechnology 54: 304-316. https://doi.org/10.17113/ $\mathrm{ftb} \cdot 54.03 .16 .4413$

Mohammadi A, Hashemi M, Hosseini SM. 2015. Nanoencapsulation of Zataria multiflora essential oil preparation and characterization with enhanced antifungal activity for controlling Botrytis cinerea, the causal agent of gray mould disease. Innovative Food Science \& Emerging Technologies 28: 73-80. https:// doi.org/10.1016/j.ifset.2014.12.011

Mohammadi A, Hashemi M, Hosseini SM. 2016. Postharvest treatment of nanochitosan-based coating loaded with Zataria multiflora essential oil improves antioxidant activity and extends shelf-life of cucumber. Innovative Food Science \& Emerging Technologies 33: 580-588. https://doi.org/10.1016/j.ifset.2015.10.015

Moushib LI, Witzell J, Lenman M, Liljeroth E, Andreasson E. 2013. Sugar beet extract induces defence against Phytophthora infestans in potato plants. European Journal of Plant Pathology 136: 261-271. https://doi. org/10.1007/s10658-012-0160-9

Mukhopadhyay SS. 2014. Nanotechnology in agriculture: Prospects and constraints. Nanotechnology, Science and Applications 7: 63-71. https://doi.org/10.2147/ NSA.S39409

Nandeeshkumar P, Sudisha J, Ramachandra KK, Prakash HS, Niranjana SR, Shekar SH. 2008. Chitosan induced resistance to downy mildew in sunflower caused by Plasmopara halstedii. Physiological and Molecular Plant Pathology 72: 188-194. https://doi.org/10.1016/j. pmpp.2008.09.001

Nedovic V, Kalusevic A, Manojlovic V, Levic S, Bugarski B. 2011. An overview of encapsulation technologies for food applications. Procedia Food Science 1: 1806-1815. https://doi.org/10.1016/j.profoo.2011.09.265

Nunes GL, Boaventura BCB, Pinto SS, Verruck S, Murakami FS, Prudêncio ES, Amboni RDDMC. 2015. Microencapsulation of freeze concentrated Ilex paraguariensis extract by spray drying. Journal of Food Engineering 151: 60-68. https://doi.org/10.1016/j. jfoodeng.2014.10.031

Oliveira CM, Auad AM, Mendes SM, Frizzas MR. 2014. Crop losses and the economic impact of insect pests on Brazilian agriculture. Crop Protection 56: 50-54. https:// doi.org/10.1016/j.cropro.2013.10.022

Pang J-Y, Zhao K-J, Wang J-B, Ma Z-J, Xiao X-H. 2014. Green tea polyphenol, epigallocatechin-3-gallate, possesses the antiviral activity necessary to fight against the hepatitis B virus replication in vitro. Journal of Zhejiang University-SCIENCE B 15: 533-539. https:// doi.org/10.1631/jzus.B1300307

Pereira AES, Silva PM, Oliveira JL, Oliveira HC, Fraceto LF. 2017. Chitosan nanoparticles as carrier systems for the plant growth hormone gibberellic acid. Colloids and Surfaces B: Biointerfaces 150: 141-152. https://doi. org/10.1016/j.colsurfb.2016.11.027

Prasad R, Bhattacharyya A, Nguyen QD. 2017. Nanotechnology in sustainable agriculture: Recent developments, challenges, and perspectives. Frontiers in Microbiology 8: 1014. https://doi.org/10.3389/ fmicb.2017.01014

Rabbani MM, Ahmed I, Park SJ. 2016. Application of nanotechnology to remediate contaminated soils. In: Hasegawa H, Mofizur-Rahman IM, Azizur-Rahman M, editors. Environmental Remediation Technologies for Metal-Contaminated Soils. Tokyo, Springer. P. 219-229.

Ramírez-Legarreta MR, Jacobo-Cuéllar JL. 2002. Impacto ambiental del uso de plaguicidas en huertos de manzano del noroeste de Chihuahua, México. Revista Mexicana de Fitopatología 20: 168-173.

Ribes S, Fuentes A, Talens P, Barat JM, Ferrari G, Donsì F. 2017. Influence of emulsifier type on the antifungal activity of cinnamon leaf, lemon and bergamot oil nanoemulsions against Aspergillus niger. Food Control 73: 
784-795. https://doi.org/10.1016/j.foodcont.2016.09.044

Rodríguez-Guadarrama HA, Guevara-González RG, Romero-Gómez SdJ, Feregrino-Pérez AA. 2018. Antifungal activity of Mexican endemic plants on agricultural phytopathogens: A review. XIV International Engineering Congress (CONIIN). IEEE. Querétaro, México.

Rossetti A, Mazzaglia A, Muganu M, Paolocci M, Sguizzato M, Esposito E, Cortesi R, Balestra GM. 2017. Microparticles containing gallic and ellagic acids for the biological control of bacterial diseases of kiwifruit plants. Journal of Plant Diseases and Protection 124: 563-575. https://doi.org/10.1007/s41348-017-0096-6

Roy A, Singh SK, Bajpai J, Bajpai AK. 2014. Controlled pesticide release from biodegradable polymers. Central European Journal of Chemistry 12: 453-469. https://doi. org/10.2478/s11532-013-0405-2

Sagiri SS, Anis A, Pal K. 2016. Review on encapsulation of vegetable oils: Strategies, preparation methods, and applications. Polymer-Plastics Technology and Engineering 55: 291-311. https://doi.org/10.1080/036025 59.2015.1050521

Salatin S, Barar J, Barzegar-Jalali M, Adibkia K, Kiafar F, Jelvehgari M. 2017. Development of a nanoprecipitation method for the entrapment of a very water soluble drug into Eudragit RL nanoparticles. Research in Pharmaceutical Sciences 12: 1-14. https://doi. org/10.4103/1735-5362.199041

Sandoval-Peraza VM, Cu-Cañetas T, Peraza-Mercado G, Acereto-Escoffié POM. [internet]. 2017. Introducción en los procesos de encapsulación de moléculas nutracéuticas. [cited 2019 October 20]. Available in: https://www. omniascience.com/books/index.php/monographs/ catalog/view/98/421/857-1.

Satalkar P, Elger BS, Shaw DM. 2016. Defining nano, nanotechnology and nanomedicine: Why should it matter? Science and Engineering Ethics 22(5): 1255-1276. https:// doi.org/10.1007/s11948-015-9705-6

Sattary M, Amini J, Hallaj R. 2020. Antifungal activity of the lemongrass and clove oil encapsulated in mesoporous silica nanoparticles against wheat's take-all disease. Pesticide Biochemistry and Physiology 170: 104696. https://doi.org/10.1016/j.pestbp.2020.104696

Shabana YM, Abdalla ME, Shahin AA, El-Sawy MM, Draz IS, Youssif AW. 2017. Efficacy of plant extracts in controlling wheat leaf rust disease caused by Puccinia triticina. Egyptian Journal of Basic and Applied Sciences 4:
67-73. https://doi.org/10.1016/j.ejbas.2016.09.002

Sharma A, Rajendran S, Srivastava A, Sharma S, Kundu B. 2017. Antifungal activities of selected essential oils against Fusarium oxysporum f. sp. lycopersici 1322, with emphasis on Syzygium aromaticum essential oil. Journal of Bioscience and Bioengineering 123: 308-313. https:// doi.org/10.1016/j.jbiosc.2016.09.011

Shishir MRI, Xie L, Sun C, Zheng X, Chen W. 2018. Advances in micro and nano-encapsulation of bioactive compounds using biopolymer and lipid-based transporters. Trends in Food Science \& Technology 78: 34-60. https://doi.org/10.1016/j.tifs.2018.05.018

Slusarenko AJ, Patel A, Portz D. 2008. Control of plant diseases by natural products: Allicin from garlic as a case study. In: Collinge DV, Munk L, Cooke BM, editors. Sustainable Disease Management in a European Context. Dordrecht, Springer. P. 313-322.

Spadari CC, Lopes LB, Ishida K. 2017. Potential use of alginate-based carriers as antifungal delivery system. Frontiers in Microbiology 8: 97. https://doi.org/10.3389/ fmicb.2017.00097

Suwannateep N, Banlunara W, Wanichwecharunggruang SP, Chiablaem K, Lirdprapamongkol K, Svasti J. 2011. Mucoadhesive curcumin nanospheres: Biological activity, adhesion to stomach mucosa and release of curcumin into the circulation. Journal of Controlled Release 151: 176-182. https://doi.org/10.1016/j.jconrel.2011.01.011

Vemmer M, Patel AV. 2013. Review of encapsulation methods suitable for microbial biological control agents. Biological Control 67: 380-389. https://doi.org/10.1016/j. biocontrol.2013.09.003

Venugopala KN, Rashmi V, Odhav B. 2013. Review on natural coumarin lead compounds for their pharmacological activity. BioMed Research International 2013: 963248. http://doi.org/10.1155/2013/963248

Vergnes S, Ladouce N, Fournier S, Ferhout H, Attia F, Dumas B. 2014. Foliar treatments with Gaultheria procumbens essential oil induce defense responses and resistance against a fungal pathogen in Arabidopsis. Frontiers in Plant Science 5: 477. https://doi.org/10.3389/ fpls.2014.00477

Verlee A, Mincke S, Stevens CV. 2017. Recent developments in antibacterial and antifungal chitosan and its derivatives. Carbohydrate Polymers 164: 268-283. https://doi. org/10.1016/j.carbpol.2017.02.001

Wang W, Ben-Daniel BH, Cohen Y. 2004. Control of plant diseases by extracts of Inula viscosa. 
Phytopathology 94: 1042-1047. https://doi.org/10.1094/

PHYTO.2004.94.10.1042

Wang Y, Bian W, Ren X, Song X, He S. 2018. Microencapsulation of clove essential oil improves its antifungal activity against Penicillium digitatum in vitro and green mould on Navel oranges. The Journal of Horticultural Science and Biotechnology 93: 159-166. https://doi.org/10.1080/14620316.2017.1345332

Wink M. 2011. Annual Plant Reviews, Biochemistry of Plant Secondary Metabolism. Wiley Blackwell. West Sussex, UK.

Wu K, Fang Z, Guo R, Pan B, Shi W, Yuan S, Guan H, Gong M, Shen B, Shen Q. 2015. Pectin enhances bio-control efficacy by inducing colonization and secretion of secondary metabolites by Bacillus amyloliquefaciens SQY 162 in the rhizosphere of tobacco. PloS ONE 10: e0127418. https://doi.org/10.1371/journal.pone.0127418

Zhaveh S, Mohsenifar A, Beiki M, Khalili ST, Abdollahi A, Rahmani-Cherati T, Tabatabaei M. 2015. Encapsulation of Cuminum cyminum essential oils in chitosan-caffeic acid nanogel with enhanced antimicrobial activity against Aspergillus flavus. Industrial Crops and Products 69: 251-256. https://doi.org/10.1016/j. indcrop.2015.02.028 